Konstantinos Agaliotis ${ }^{1}$

Miroljub Hadžić ${ }^{2}$
JEL: D12

DOI: 10.5937/industrija43-8659

UDC: 005.346:336.717

Original Scientific Paper

\title{
Can retail banking clients' attrition be managed?
}

\author{
Article history: \\ Received: 29 April 2015 \\ Sent for revision: 22 May 2015 \\ Received in revised form: 27 August 2015 \\ Accepted: 2 September 2015 \\ Available online: 15 October 2015
}

\begin{abstract}
The purpose of all banks across the universe is to satisfy their clients' necessities. One of the predominant impacts of the last few years' financial crisis in Europe was the way in which customers interact with their banks. The theory of "main bank" is not any more the case as clients' trust toward banks fades away together with their loyalty. Nowadays, it is necessary for banks to segment their clientele data base, and target the most profitable clients. The retention strategy of each financial institution becomes more and more important as the value of each retained customer is disproportional to the cost of acquiring a new one. The main findings of the subject retail banking clients' retention policy analysis prove that clients of different lifetime value have different propensity to defect. At the same time, the ability of a bank to retain a potential defector does not depend directly on satisfying the defection reason. Many of the various bank counter offers which do not directly satisfy the reason that a client refers to as the "defection" one, are enough in order to retain a client. Equally important to the identification of clients' behavioural patterns is the use of the subject findings on behalf of the retail oriented banks in order to predict accurately the cost of future defection, as well as, to incorporate one more measurable parameter in their credit risk scorecards i.e. the intention to increase credit exposure.
\end{abstract}

Keywords: Retail Banking, Clients retention strategies, Segmentation of clients.

\footnotetext{
${ }^{1}$ Alpha Bank Serbia, agaliotisk@gmail.com

${ }^{2}$ Singidunum University Belgrade, Serbia 
Agaliotis K., Hadžić M.: Can retail banking clients' attrition be managed?

\title{
Može li se upravljati odlivom klijenata u bankarskom poslovanju sa stanovništvom?
}

\begin{abstract}
Apstrakt: Cilj svih banaka širom sveta je da zadovolje potrebe svojih kljenata. Jedan od najuočljivijih efekata višegodišnje finansijske krize u Evropi bio je način na koji klijenti sarađuju sa svojim bankama. Teorija o jedinoj, takozvanoj "glavnoj banci“ više nije validna, budući da se poverenje klijenata u banke smanjuje uporedo sa njihovom lojalnošću. U današnje vreme je neophodno da banke izvrše segmentaciju svojih klijenata, sa ciljem da se usredsrede na klijente koji će doneti najveći profit. Strategija zadržavanja klijenata u svim finansijskim institucijama dobija sve veći značaj pošto je vrednost svakog zadržanog klijenta u nesrazmeri sa troškovima akvizicije novog klijenta. Najvažniji nalaz predmetne analize politike zadržavanja fizičkih lica, klijenata banaka dokazuje da klijenti sa različitim očekivanom profitom tokom čitavog trajanja poslovnog odnosa s bankom (engl. lifetime value) imaju različitu sklonost prelaska u drugu banku. Istovremeno, sposobnost banke da zadrži klijenta koji bi potencijalno mogao da pređe u drugu banku ne zavisi direktno od toga da li će postojeća banka da zadovolji razlog za prelazak u drugu. Brojne kontraponude drugih banaka koje ne zadovoljavaju direktno razlog koji klijent navodi kao razlog da „prebegne“ u drugu banku su dovoljni da klijent bude zadržan. Jednako važni za identifikaciju obrasca ponašanja klijenata su, kako pokazuje istraživanje, pravovremeno izračunavanje troškova budućih napuštanja banke od strane klijenata fizičkih lica, kao i uključivanje u kreditni rizik faktora koji je merljiv, a odnosi se na spremnost klijenta da poveća sopstvenu kreditnu izloženost.
\end{abstract}

Ključne reči: bankarsko poslovanje sa stanovništvom, politika sprečavanja odliva klijenata, segmentacija klijenata

\section{Introduction}

Based on various customers' satisfaction surveys, it has been verified that the relation between customer satisfaction and loyalty is neither stable, nor reliable (Kaplan et al., 1996). Aggressive competition pricing policies can influence clients with high loyalty levels and have them switched to much cheaper vendors to satisfy their needs (Heskett et al., 1994).

The existence or not of intense competition and the possible cost of changing banks are the main factors to contribute to retail banking clients' defection (Ernst\& Young, 2010. Other factors such as the service level, the innovation level, the access to alternative communication (Rootman et al. 2011), the duration of the relationship with the bank (Reed, 2006), the age (Capgemini, 2012), the number of cross-sold products, being the main bank (Roy and Shehkar 2010), or proximity to home/work are not to be disregarded. 
Agaliotis K., Hadžić M.: Can retail banking clients' attrition be managed?

Many banks have invested in developing models to predict the risk of future defectors. Others consider equally important the adoption of predictive models for customers handling as soon as the definite will of clients to defect has been detected.

The reason is obvious: the longer a client stays with a bank, the higher the value he/she represents to the bank (Kandampully\&Duddy, 1999), the less time consumed for the bank, the less sensitive to price, the higher the probability to bring new clients in (Reichheld\& Frederick 1996) and so on. At the same time, the decision to disinvest from loss making clients is part of integrated business policies and cannot be overlooked (Mittal et al., 2008).

The following paper tries to elaborate on a model that is threefold. At first, it categorizes clients according to their lifetime value. Secondly, it concludes on what the best counter offer to future defectors according to their lifetime value and reason of defection. Thirdly, it proves that certain clients' profiles have the inclination to defect more than others.

Unlike similar scholar (Gouws, 2012) or business studies (Delloitte, 2013), which aim to understand the main contributors that motivate retail banking defectors, this paper is a research case which elaborates both on the anticipated behaviour of defectors after they expressed their final will to cancel a major retail banking product, and concluding on whether different types of lifetime value clients intend to defect more or not.

At the centre of focus will be clients of a major retail banking product see, Credit cards. The data derive from 8.364 counter offers provided to credit cards holders living in Serbia from August 2013 to October 2014. The sample represents $26 \%$ of the entire credit cards holders population of a particular bank operating in the Serbian Market, here named bank A. Considering both the absolute and the relative value of counter offers against the overall population one can say that the findings are statistically relevant.

All counter offers were provided to clients only after having expressed their final will to cancel their credit card.

\section{Methodology of research}

The basis of the subject retention strategy considered that all potential defectors might be retained once they agree with a counter offer that satisfies their needs. The methodology used required customers to be segmented based on their lifetime value to the bank, compare the acceptance of various counters offers vs. the defection reason and the client value category and finally, use the over/underrepresentation theory to prove that different clients' categories have different propensity to defect. 
Agaliotis K., Hadžić M.: Can retail banking clients' attrition be managed?

Therefore, not all different potential defectors have been presented with the same counter offer, as clients of high lifetime value were presented with counter offers of higher value and vice versa. The same is also the case for potential defectors of the same lifetime value that were presented various counter offers provided that their defection reason differed.

The particular criteria and methodology used for both segmenting clients based on their lifetime value, as well as proving that particular lifetime value categories have different inclination to defect are presented in the following chapters $2 \& 4$.

\section{Lifetime value of clients}

Life time value can be defined as "the present value of all future profits obtained from a customer over his/her life of relationship with a firm (Gupta et al., 2006).

The use of the customer life time value theory (CLV) is important as marketing managers will use it for defining how much companies are willing to spend for acquiring new clients, or come to conclusions on how much each category of clients is worth.(Panda, 2006), (Symonds et al., 2007)

The understanding of CLV in a banking environment results in many strategic clients related decisions. The banks that know the value of their clients:

1. Have a customer centric approach, offering more to the clients that are worth it. (Bain\& Company, 2011).

2. Use wisely their resources by focusing on the most promising clients.

3. Disengage in time from the relation with the non - promising clients.

4. Budget efficiently and get the maximum out of their retail market.

The subject Credit cards retention policy followed a customer life time value approach by segmenting future defectors into 4 value groups from $A$ to $D$, group D amassing all accounts in delinquency of $90 \mathrm{dpd}$ or more, while groups A-C were created initially based on two factors:

1. average \% of outstanding balance reached from the approved limit (an indicator of the generated interest revenue)

2. average \% of monthly usage from the approved limit (an indicator of the cash advance behaviour and the generated commissions \& fees revenue)

The two factors were calculated based on the previous 6 months accounts 
Agaliotis K., Hadžić M.: Can retail banking clients' attrition be managed?

history to take into account two important factors:

- $\quad$ seasonality factor for usage and

- minimum outstanding balance build-up period

Historical data proved that the variance of the portfolio's two dimensions changes with $\pm 5 \%$ margin from month to month, therefore the following group distribution is set as rule on defining the boundaries of the first 3 groups:

- Group A not to exceed $15 \%$ of the active portfolio;

- Group B to represent between $35-45 \%$ of the active portfolio;

- Group C to represent between $30-40 \%$ of the active portfolio;

A cluster analysis was performed on the active portfolio to identify the general historic patterns of accounts regarding the two factors. Therefore, 5 clusters were identified that amass $75 \%$ of the active portfolio, cluster 0 and 1 being the most dense ones (table 1).

Table 1. Usage concentration of credit cards

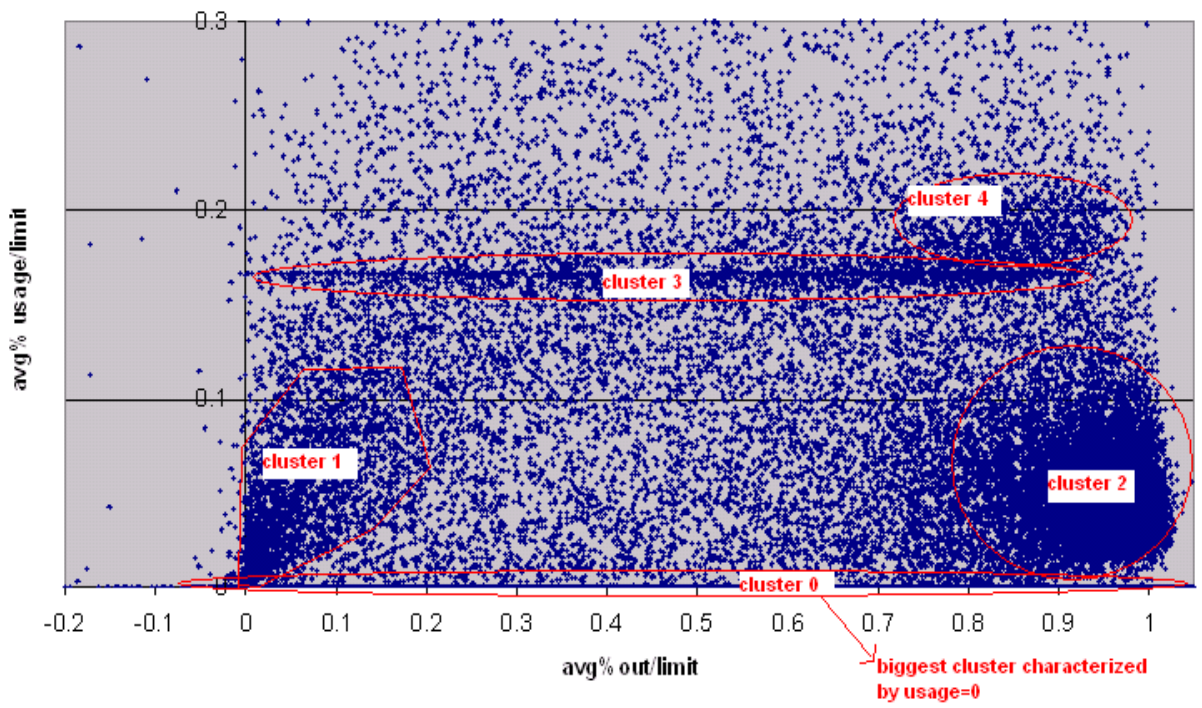

Source: Author

The following group boundaries were set based on the cluster analysis of the initial data used (table 2): 
Agaliotis K., Hadžić M.: Can retail banking clients' attrition be managed?

- Group A: avg\%Usage/limit<=0 \&avg\%OB/limit<=1 \& above boundary F1

- Group B: is defined by eliminating groups $A$ and $C$ from the active portfolio

- Group C: avg\%Usage/limit<0 \&avg\%OB/limit>1 \& below boundary F2

Table 2 - Credit cards holders groups' boundaries

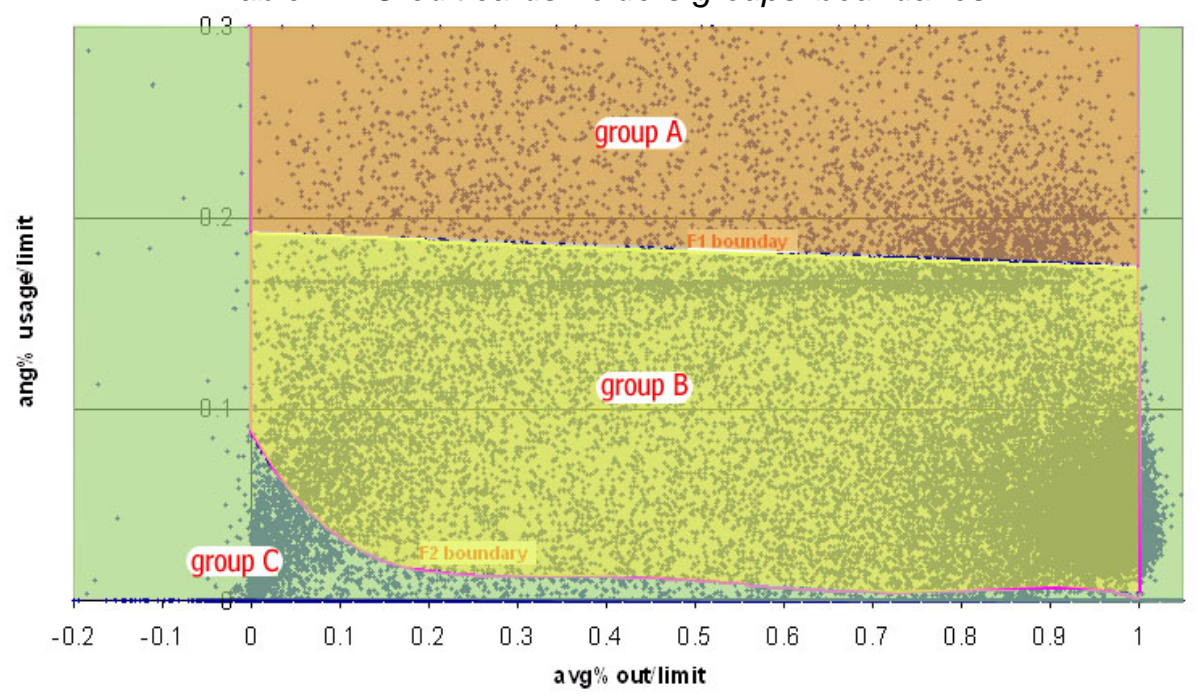

Source: Author

Boundaries F1 and F2 are to be updated at the beginning of each month, in order to control the population size on each group and therefore to comply with the groups distribution

The Participation of the different groups, after applying the above mentioned criteria on the client portfolio, was as follows: A - 14\%, B - 44\%, C - 41\%, D $1 \%$.

\section{Results of anti-attrition policy for Credit Cards}

Having already experienced the provision of counter offers to 8.364 potential credit card defectors, resulted into the findings depicted in appendix 1 . The table results, for the purpose of being concise, include only the cases where at least one counter offer was accepted from the potential defectors. 
Agaliotis K., Hadžić M.: Can retail banking clients' attrition be managed?

A distinction between the presented columns "No. of offers proposed" and "No. of offers accepted" needs to be made. While the latter is strictly linked to the particular offer accepted by potential defectors, the former refers to the reason for defection which was indeed supported by more than one counter offers presented to the client to choose from. As such, the figures appearing in the column "No. of offers proposed" cannot be considered cumulatively.

The results are sorted in the following order:

1) Clients 'category A-D

2) Accepted counter offers' percentage over the total accepted counter offers of the same clients' category

3) Accepted counter offers' percentage over the total accepted counter offers of all clients categories

The results are very interesting, as only in one case (potential reason for defection: annual fees), the counter offer succeeded in retaining a defector by offering something directly linked to the reason for defection (counter offer: $50 \%$ decrease of annual fees).

Surprisingly, all potential defectors that declared "personal reasons", as their reason of defection, are extremely difficult to be retained (8.7\%). Defectors who have already been approached by other banks to consolidate their debts which include their credit cards, appears to be motivated not to share this info with their cards issuing bank. The substantial number of cases (2.521) recorded with that reason leads to that conclusion if it is also compared with the effectiveness recorded by the same counter offers for other defecting reasons and especially the "refinancing loan with/without disbursement fees"( $47,45 \%$ of accepted counter offers).

Also, as refinancing loans rank high in the acceptance rates, it needs to be pointed out that their acceptance, as a retaining tool is observed to more than one potential defection reasons. Among them are the credit card's high interest rates, the intention of the client to apply for another credit product, or the intention to decrease his/her current credit exposure.

The well-established relation between clients and branch service level is not proved after the studied anti-attrition policy results. This is because only $3.3 \%$ of potential defectors declared as "branch dissatisfaction" the reason for the potential cards cancellation. This, together with the low number of defection reasons attributed to the high interest rate, leads us to conclude that credit cards holders are not price or service sensitive.

Contradicting findings may also be noticed. Firstly, those clients wishing to increase their "Open to Buy" who were retained after they were offered a new cash loan, and secondly those clients wishing to decrease their credit cards 
Agaliotis K., Hadžić M.: Can retail banking clients' attrition be managed?

annual fees that were retained by new refinancing loans. The same stands for clients wishing to buy another bank's credit product who were retained by a refinancing loan.

Still, a significant observation should not go unnoticed. When observing the ability to retain a potential defector claiming the same defection reason among different clients' categories, it is noticed that the different clients 'categories have also different retention ratios. A good example can be the "personal reasons" among the different clients' categories. Being indeed the most unpredicted reason for defection it shows the following retention rate among clients' categories: A 13.4\%, B 12.8\%, C 3.9\%, D 5.8\%

Although different types of counter offers attributed to the overall retention rate of each client category, it is obvious that not only different reasons of potential defection lead to different retention rates but also, that the overall clients categories indicating different outstanding balance, usage, current or not repayment characteristics can be retained to a different degree. The overall retention rate per client category was:

Table 3. Retention rate per client category

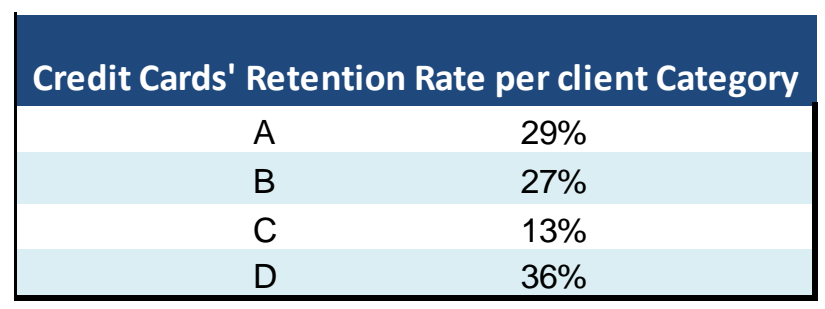

Source: Author

The analysis followed a twofold approach in order to prepare the counter offers. Firstly, it made any effort to decrease the profitability of the bank at the expense of a retained customer. In this direction, whatever seemed to be the main defection reason, the counter offer was always based exactly on what it could instantly reduce the clients' cost and therefore the bank's profitability. Secondly, it was requested to think "out of the box" and prepare counter offers that are not necessarily directly linked to the financial need of the potential defectors. Therefore, proposals were prepared in such a way that they would try also to consider other confirmed aspects of the subject clients. The cards holders' sales profile was taken in consideration for that reason. Particularly, both the existing use of other consumer finance products and findings over their "propensity to buy" of other consumer finance products were considered. 
Agaliotis K., Hadžić M.: Can retail banking clients' attrition be managed?

However, it was assumed that should such close relationship be already confirmed by studying their sales behaviour, it could only help to add to the counter offers elements of other consumer lending related products. The three examples of the contradicting cases described above, where the credit cards originated concern was solved by offering cash/refinancing loans prove the interrelation of credit cards holders' behaviour not only during the initial acquisition phase, but also during the defection one.

An additional confirmation of this aspect can also be derived from the cases of clients wishing to decrease their cards' interest rate, retained after having been offered a new cash loan. Although not pragmatic and contradicting any logic that seeks to find truth in decreasing monthly obligations by approving additional credit, this finding is true and has been observed in a considerable portion of category B clients.

\section{Over/underrepresentation and anti-attrition policy}

The subject methodology is based on the over/under representation principle in order to prove that different client categories have a higher propensity to defect. According to it, an overrepresentation event occurs when a figure is "greater, or in a proportion that is greater, than is statistically expected or warranted" (Webster's New World College Dictionary 2010).

The methodology considers the percentage split of sub - segments between two similar micro societies. A simple example can be the professions or educational levels, which make up the existing portfolio of any clientele's data base.

Should the percentage representing the profession "Doctors" remain the same between the initial credit cards universe and the clients who expressed their final will to cancel their credit card, we may conclude that "Doctors" have the same proportional tendency to cancel their credit cards as compared to the overall average tendency of the credit cards holders' portfolio. If "Doctors" are overrepresented in the list of clients who expressed their will to cancel their credit cards, we conclude that they intend to have higher propensity to express their will to cancel their cards as compared to the overall average of the credit cards holders' portfolio.

In an environment that bank initiates a particular product offering, it is exactly the opposite reason that leads a segment not to exist or to be under represented in the final clients' list. Its "indifference" is explained by the prospect's negative answer to the product offering that will result in having no representation of the particular segment in the final list of clients. 
Figure 1. Overrepresentation theory

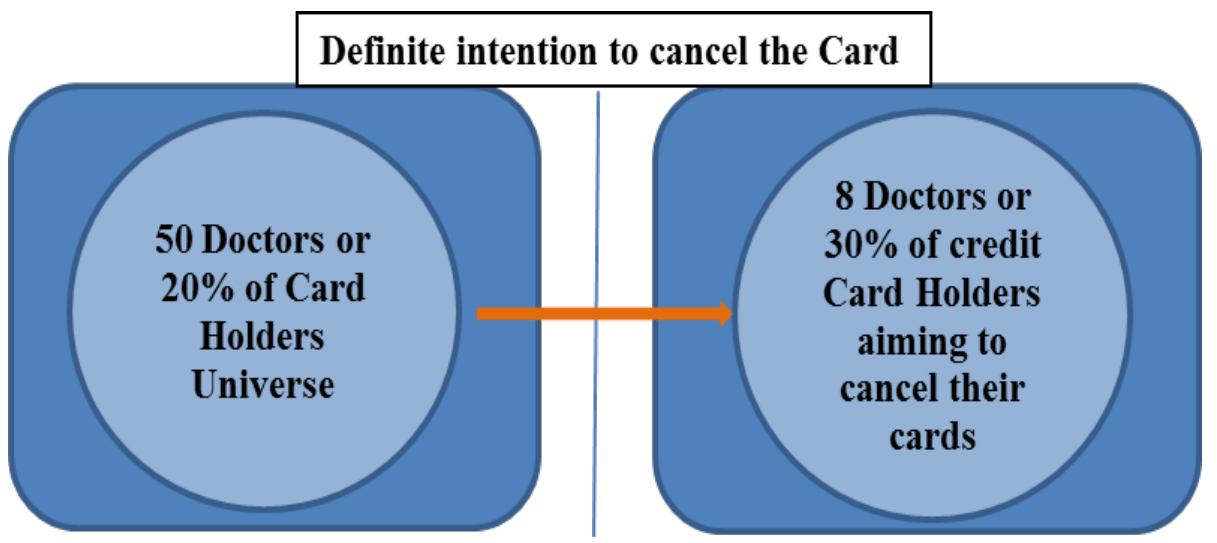

Propensity to defect: $30 \% / 20 \%=1.5$.

Doctors are overrepresented when they express their will to cancel their cards vs. their initial representation in the Cards Holders Universe

Source: Author

Following the application of the same approach during the implementation of the anti-attrition policy, and more specifically observing the representation of each client's category in a. the overall credit cards portfolio and b. after they expressed their will to cancel their credit card, we notice:

Table 4. Over/underrepresentation and anti-attrition policy

\begin{tabular}{|l|r|r|r|r|}
\hline Category & No. Of accounts - & No of AA offers - & \% Of accounts - & \% of AA offers - \\
\hline A & 4466 & 1701 & $13.90 \%$ & $20.34 \%$ \\
\hline B & 13966 & 3318 & $43.48 \%$ & $39.67 \%$ \\
\hline C & 13463 & 3227 & $41.91 \%$ & $38.58 \%$ \\
\hline D & 227 & 118 & $0.71 \%$ & $1.41 \%$ \\
\hline Total & 32122 & 8364 & $100.00 \%$ & $100.00 \%$ \\
\hline
\end{tabular}

Source: Author

The column "No. of accounts-" and "No of AA offers-" depict the actual Credit cards portfolio and the number of anti-attrition offers, while the next two columns to the right the same figures represented in percentage. It is noticeable that, categories $A$ and $D$ are overrepresented, which means that they have a higher propensity to express their willingness to cancel their credit cards compared to the categories B and C. 
Agaliotis K., Hadžić M.: Can retail banking clients' attrition be managed?

The finding should not be surprising as all banks seek via different sources the "profitable" clients of their competitors. Practices like the "instant credit worthiness check" at branch network level aim exactly at identifying the high net worth value clients and make subsequently attractive offers for refinancing.

The overrepresentation in category $\mathrm{D}$ (delinquent clients) is also characterised by a relatively high percentage of "personal reasons" as the origin of defection.

An explanation for this is the unwillingness of delinquent credit card holders to continue having in their wallet a revolving credit tool that already proved to take them far beyond the frontiers of their financial capabilities. Regardless the non - performing loans (NPL) strategy of each retail bank, the intention of delinquent clients to cancel their product at a stage where both debt collections and restructuring loans efforts failed, should not go unnoticed.

\section{Conclusions}

The overall anti-attrition policy analysis led to very interesting conclusions. Firstly, it proved that not all clients can be managed with the same success. It has not only be proven the existence of different retention rates among clients of different lifetime values, but also confirmed in practice what future defectors need to be offered as a retention tool.

Surprisingly, the very logical assumption of clients being retained after having been counter offered a proposal directly linked to their "defection" reason is not proven. With the exemption of decreasing the credit cards annual fees, it has also been confirmed the paradox of the willingness of future defectors to "stay" with the current bank by increasing their credit exposure and not by decreasing it.

Other important findings that should not be unnoticed are the low importance of service satisfaction and the time sensitivity of the counter offer proposal. As the trigger event for initiating the anti-attrition process was the moment when a client was expressing his definite will to cancel his credit card, the relative high number of defection reasons "personal reasons" can be associated with the offer already provided by competitive banks. Given that this type of defection reasons were in fact not manageable, leads to second thoughts about the importance of proactive actions in order to identify future defectors.

It is important to note that a great part of the analysis and the respective findings represent a model that is subject to on-going evaluation and readjustment. Thus, the definition of clients' value is subject to a different 
Agaliotis K., Hadžić M.: Can retail banking clients' attrition be managed?

evaluation given different business strategies of a bank in different periods of time. The same stands for the cost of the counter offers and respectively how much each bank is willing to "sacrifice" for retaining existing clients. What cannot be debated is that regardless of the significance attributed by different banks to the value of their clients, and the amount that they are willing to spend in order to retain potential defectors, the research and the study of their clients' needs is a must. In this light, the continuation of identifying the right counter offers for the right clients segments, and the use of the most well accepted counter offers should become the subject of permanent research for all financial institutions. The dimensions of this research are worth looked into by comparing also similar findings with other banks in Serbia, or in countries in transition with a similar banking sector.

The existence of certain statistical proven counter offers does not also mean that other important customer experience factors need to be minimised. The selection of the proper communication tool, see branch network employees, contact centre, headquarters staff, to combine the best cost efficiency with the most qualitative results is an issue that goes beyond the prediction of behaviour for anti-attrition reasons.

The behavioural patterns identified should not only be seen as ways to predict a more accurate budget or increase clients' retention. A contribution to banking science is present as for the first time the propensity to defect is measured in similar way as the ones to buy or to defect. The obvious findings calling for clients intentions to increase their credit exposure or reply positively to $\mathrm{x}$ or $\mathrm{y}$ offers need to be incorporated into the credit tools of every bank. Therefore, the proven case of clients' intention can be a part of any credit scorecard, as it is already the case for income, property ownership, age, etc.

As the particular tools already exist, see multiple regression analysis for setting scorecard cut off scores, the introduction of a new field (intention) will definitely deliver great value in assessing future customer propensity to increase credit exposure. (Bijak, 2011)

Provided that the preparation of the annual retail banking business budgets contains as mandatory elements the "enablers" part, which requires managers to justify the anticipated retention expectations, the methodology presented above becomes not only useful, but also necessary. It can support clients' retention expectations and the day-to-day handling of potential defectors as the best statistically accepted counter offer, will secure not only high retention rates but the bonding of the right offer to the most valuable clients. 
Agaliotis K., Hadžić M.: Can retail banking clients' attrition be managed?

\section{References}

Bain \& Company, (2011), Customer Loyalty in Retail Banking, Americas, Inc., p 6 Bijak, (2011), Journal of the Operational Research Society, p. 2

Capgemini, (2012), World Retail Banking Report, Retrieved from http://www.capgemini.com/wrbr12.

Deloitte, (2013), Retail Bank Pricing -Resetting customer expectations, Deloitte Center for Financial Services

Ernst \& Young, (2010), Understanding customer behavior in retail banking, the impact of the credit crisis across Europe

Gouws N., (2012), Identifying factors that influence customer retention in a South African retail bank, Potchefstroom Business School, North-West University.

Gupa et al, (2006), Modelling customer lifetime value, Journal of Service Research, Volume 9, No. 2, pp 141

Heskett, J., James L. et al, (1994), Putting the Service-Profit Chain to Work, Harvard Business Review, Vol. 72, No. 2, pp 164-174.

Kandampully, J. \&Duddy, R., (1999), Relationship marketing: a concept beyond primary relationship, Marketing Intelligence and Planning 17(7), pp 315-323.

Kaplan, R., Robert S. \&Norton, P., (1996), The Balanced Scorecard: Translating Strategy into Action, Harvard Business School Press, Boston, Massachusetts, USA.

Mittal, V., and Sarkees, M. \&Feisal, M., (2008), The Right Way to Manage Unprofitable Customers, Harvard Business Review, Vol. 86, No. 4, p.99

Panda T., (2006), Creating customer lifetime value through effective CRM in financial services industry. Journal of Services Research, Vol. 2 , pp 157-171

Reed D, (2006), Customers for keeps, MarketingWeek, Vol 37

Reichheld, F., (1996), Learning from Customer Defections, Harvard Business Review, Vol. 74, No. 2, p 57.

Roy SK. \&Shekhar V., (2010), Dimensional hierarchy of trustworthiness of financial service providers, International Journal of Bank Marketing, Vol. 18, No 1, pp :47-64.

Rootman C., Tait M. \& Bosch J., (2011), Variables influencing customer relationship management of banks, Southern African Business Review, Vol. 15, No 3, pp 184-206.

Symonds, M., Wright, T. \&Ott, J., (2007). The customer-led bank: how to retain. Journal of Business, Vol. 28, No 2, pp 4-12.

Webster's New World College Dictionary, (2010), Wiley Publishing, Inc., Cleveland, Ohio 


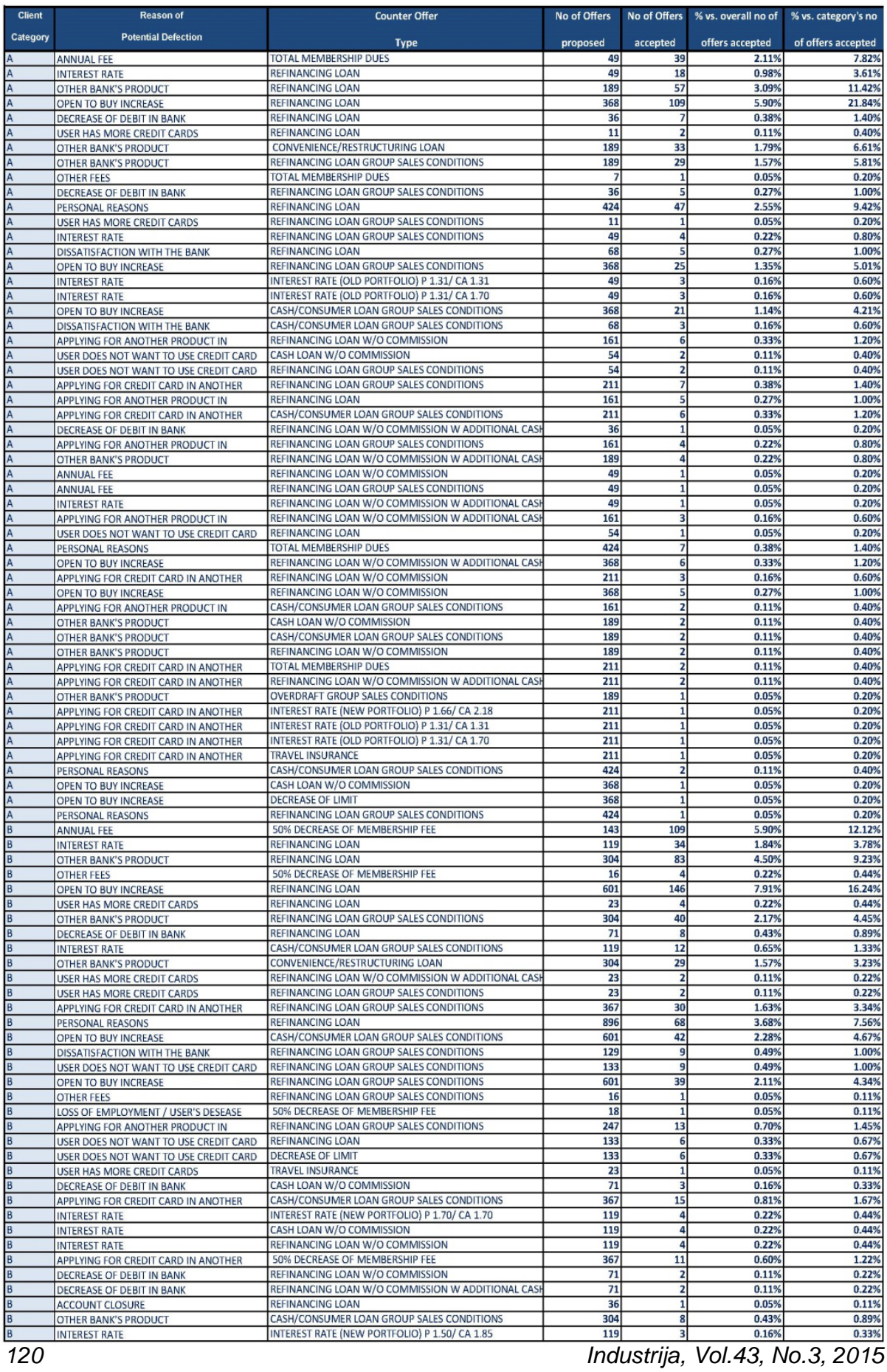


Aqaliotis K., Hadžić M.: Can retail banking clients' attrition be manaqed?

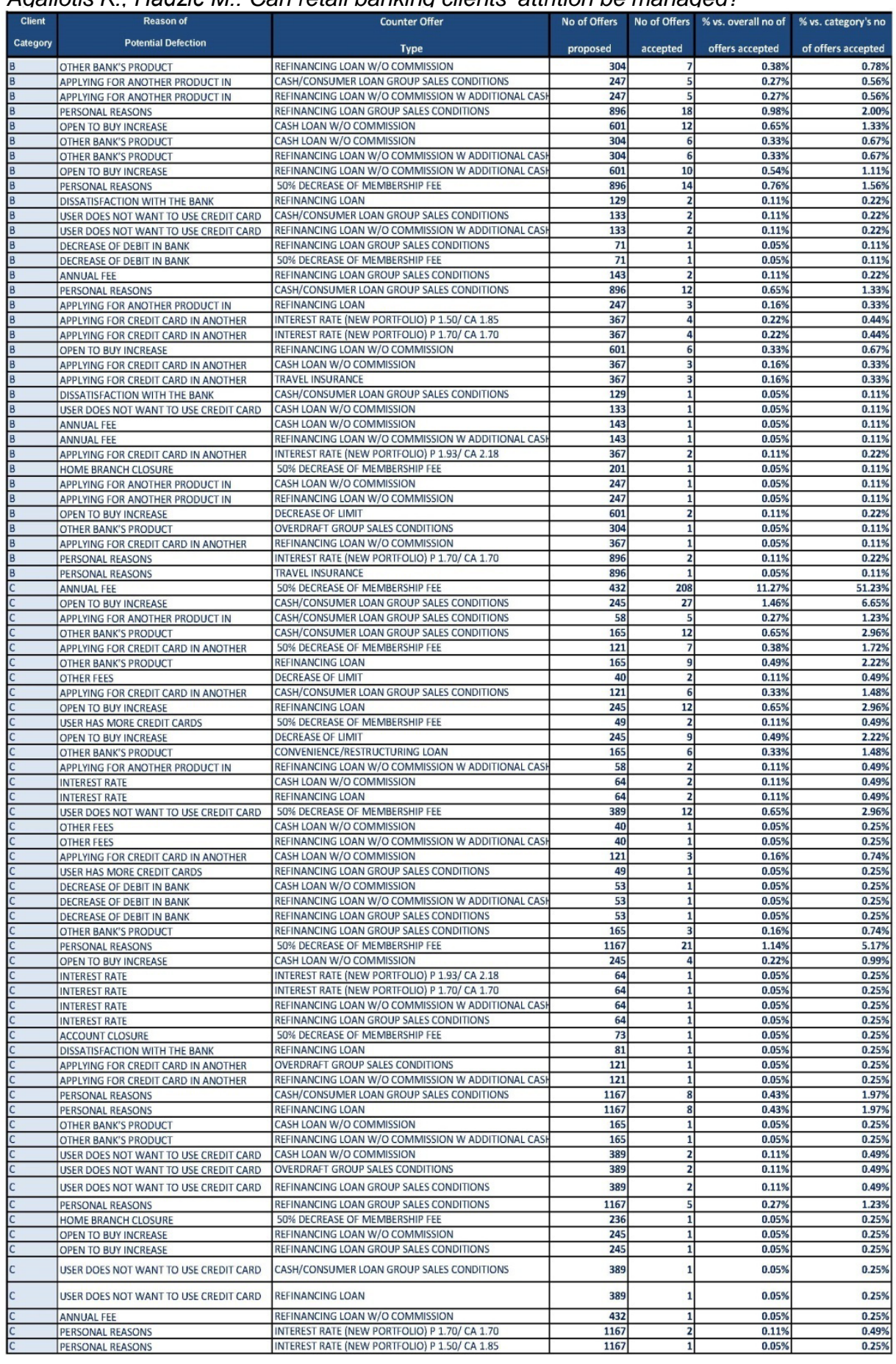

Industrija, Vol.43, No.3, 2015 
Agaliotis K., Hadžić M.: Can retail banking clients' attrition be managed?

\begin{tabular}{|c|c|c|c|c|c|c|c|}
\hline \begin{tabular}{|c|} 
Client \\
Category \\
\end{tabular} & $\begin{array}{c}\text { Reason of } \\
\text { Potential Deféction }\end{array}$ & $\begin{array}{c}\text { Counter Offer } \\
\text { Type }\end{array}$ & $\begin{array}{l}\text { No of Offers } \\
\text { proposed }\end{array}$ & \begin{tabular}{|c|} 
No of Offers \\
accepted
\end{tabular} & $\begin{array}{c}\text { \% vs. overall no of } \\
\text { offers accepted }\end{array}$ & $\begin{array}{l}\text { \% vs. category's no } \\
\text { of offers accepted }\end{array}$ & $\begin{array}{l}\text { \% vs. reason of } \\
\text { potential defection }\end{array}$ \\
\hline D & \begin{tabular}{|l} 
INTEREST RATE \\
\end{tabular} & REFINANCING LOAN & & & $0.05 \%$ & $2.38 \%$ & $100.00 \%$ \\
\hline D & OTHER BANK'S PRODUCT & CONVENIENCE/RESTRUCTURING LOAN & 35 & 31 & $1.68 \%$ & $73.81 \%$ & $88.57 \%$ \\
\hline D & DECREASE OF DEBIT IN BANK & REFINANCING LOAN & 7 & 3 & $0.16 \%$ & $7.14 \%$ & $42.86 \%$ \\
\hline D & $\begin{array}{l}\text { APPLYING FOR ANOTHER PRODUCT IN } \\
\text { ANOTHER BANK }\end{array}$ & REFINANCING LOAN & 6 & 2 & $0.11 \%$ & $4.76 \%$ & $33.33 \%$ \\
\hline D & OTHER FEES & REFINANCING LOAN & 3 & 1 & $0.05 \%$ & $2.38 \%$ & $33.33 \%$ \\
\hline$D$ & OPEN TO BUY INCREASE & REFINANCING LOAN & 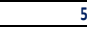 & 1 & $0.05 \%$ & $2.38 \%$ & $20.00 \%$ \\
\hline$D$ & PERSONALREASONS & REFINANCING LOAN & 34 & 2 & $0.11 \%$ & $4.76 \%$ & $5.88 \%$ \\
\hline D & OTHER BANK'S PRODUCT & REFINANSIRAJUĆI KREDIT & 35 & 1 & $0.05 \%$ & $2.38 \%$ & $2.86 \%$ \\
\hline
\end{tabular}

